\title{
E-Learning (Edublogs) Social Media Based: Its Implementation In Teaching Learning At Islamic Senior High School Bangkalan
}

\author{
Chairuddin \\ STKIP PGRI Bangkalan \\ chairuddin@stkippgri-bkl.ac.id
}

\begin{abstract}
At present, the application of internet technology in the field of education is very much needed in order to improve the quality and equitable education services. One of them in improving the quality of education is from educators (teachers). The teacher has a very crucial role in the process of teaching and learning. Therefore, the teacher must be able to provide an appropriate method and method so that the classroom atmosphere in PBM becomes enjoyable. The specific purpose of this service is that they are able to understand and properly apply elearning based learning media. The implementation is held for 2 (two) days, namely: first, the implementation of observation and the introduction process. Then the next day a workshop held on the application of e-learning based learning media. The result of this dedication is that teachers can apply e-learning based learning models in the teaching and learning process.
\end{abstract}

Keywords: Learning Media, E-learning, Teaching and Learning Process.

\begin{abstract}
Abstrak: Di masa sekarang penerapan teknologi internet di bidang pendidikan dan sangat dibutuhkan dalam rangka peningkatan kualitas dan pemerataan layanan pendidikan. Salah satu bentuk peningkatan kualitas pendidikan yaitu dari tenaga pendidik (guru). Guru mempunyai peran yang sangat krusial di tengah proses belajar mengajar (PBM). Oleh karena itu, guru harus mampu memberikan sebuah metode dan cara yang tepat agar suasana kelas di dalam PBM menjadi menyenangkan. Tujuan khusus dari pengabdian ini yaitu mereka mampu memahami dan mengaplikasikan dengan tepat media pembelajaran berbasis $e$-learning. Adapun pelaksanaanya diadakan selama 2 (dua) hari, yaitu: yang pertama, pelaksanaan observasi dan proses pengenalan. Kemudian di hari berikutnya akan diadakan workshop penerapan media pembelajaran berbasis e-learning. Hasil dari pengabdian ini yaitu guru dapat menerapkan model pembelajaran berbasis e-learning dalam proses belajar mengajar.
\end{abstract}

Kata kunci: Media Pembelajaran, E-learning, PBM. 
http://jurnalstikippersada.ac:id/jumal/index:php/JPMK

\section{Pendahuluan}

Media pembelajaran merupakan salah satu hal yang harus dipahami dan diaplikasikan oleh guru agar PBM menjadi berhasil. Oleh karenanya setiap guru harus mampu menguasai dan menerapkannya dengan baik. Adapun dalam konteks saat ini, seorang guru harus mampu memberikan bentuk media pembelajaran yang variatif dan menyenangkan, salah satunya media berbasis e-learning. Dalam hal ini, guru merupakan tokoh penting dalam penyampaian materi. Karena guru mempunyai andil besar untuk mengarahkan siswa dalam proses belajar mengajar. Apakah dalam proses tersebut menyenangkan, materi mudah diterima, dan media pembelajaran masih konvensional atau elektronik?

MA Annamirah yang terletak di daerah timur kecamatan Tanah Merah merupakan salah satu sekolah yang lokasinya di pusat kecamatan. Namun, mayoritas siswanya berasal dari desa sekitar sekolah. Dengan berbedanya latar belakang dari siswa tersebut, maka guru harus mampu memberikan sebuah PBM yang menyenangkan dengan berbagai metode dan media pembelajaran yang menarik. Dari ulasan diatas akan muncul masalah secara nyata, yaitu dari segi latar belakang pendidikan siswa tersebut sebelum menempuh jenjang madrasah aliyah atau pada saat sekarang sudah pada jenjang tersebut. Kenapa demikian, karena persoalan ini akan dapat membuat guru lebih mudah menyampaikan materi pelajaran.

Akan tetapi, permasalahan siswa disini bukanlah menjadi hal yang dominan untuk menentukan keberhasilan sebuah proses belajar dan mengajar. Ada faktor lain yang juga berperan penting selama proses tersebut berlangsung, yaitu kompetensi guru (teacher competence). Apakah guru sudah memberikan formulasi dan media pembelajaran yang pas agar siswa dapat memahami dan menerapkan materi yang disampaikan guru? Hal demikian akan memberikan dampak yang signifikan kepada siswa tersebut nantinya. Dari segi media pembelajaran, terlihat bahwa guru masih belum maksimal dalam melaksanakan pembelajaran dengan menggunakan media berbasis e-learning. Maka dari itu, sangat dirasa penting untuk melakukan kegiatan pelatihan ini di sekolah tersebut.

Berdasarkan analisis yang diperoleh dari observasi awal di sekolah tersebut, ditemukan bahwa masih banyak guru yang menerepkan media pembelajaran konvensional. Mereka melakukan hal demikian dikarenakan 
http:/jurnalstlkippersada:acid/jumal/index:php/IPMR mengalami kesulitan untuk memahami dan menerapkan media yang berbasis $e$ learning. Dengan demikian diperlukan cara agar mereka mampu memahami dan menerapkan media pembelajaran berbasis e-learning melalui sebuah pelatihan yang dapat memberikan pemahaman mengenai media pembelajaran berbasis e-learning (edublogs).

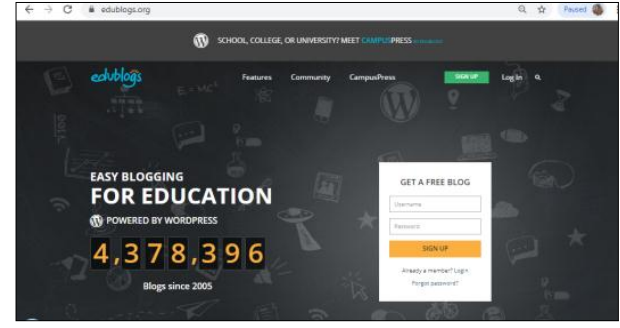

gambar 1.1 laman edublogs

Media pembelajaran online atau yang biasa disebut E-learning menyiratkan suatu proses pembelajaran yang menggunakan elektronik sebagai media pembelajaran E-learning adalah suatu bentuk teknologi informasi yang diterapkan dalam pendidikan dalam bentuk sekolah virtual. Dalam teknologi Elearning semua proses belajar mengajar yang biasanya dilakukan di kelas dilakukan secara langsung tetapi berarti virtual pada saat yang sama seorang guru mengajar di depan komputer yang ada di suatu tempat, sementara siswa mengikuti pelajaran dari komputer lain di berbagai tempat Bahan pelajaran dapat diperoleh

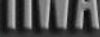

E-ISSN 2550-5800

secara gratis dalam bentuk file yang dapat diunduh, sedangkan guru dan siswa interaktif dalam bentuk tugas atau diskusi dapat dilakukan secara intensif dalam bentuk forum diskusi dan email (Masnur, 2009: 45).

E-learning pada dasarnya adalah bentuk pembelajaran konvensional yang dituangkan dalam format digital dan disajikan melalui teknologi informasi. Elearning perlu dibuat seolah-olah siswa belajar secara konvensional, hanya ditransfer ke sistem digital melalui Internet. Keuntungan e-learning yang paling menonjol adalah efisiensinya dalam penggunaan waktu dan ruang. Seperti disebutkan di atas pendidikan berbasis teknologi informasi cenderung tidak lagi tergantung pada ruang dan waktu. Tidak ada hambatan signifikan untuk melakukan kegiatan belajar mengajar di seluruh wilayah, bahkan di seluruh negara. Melalui E-learning, para guru dan siswa tidak lagi selalu harus bertatap muka di kelas pada saat yang bersamaan.

\section{METODE}

Pelaksanaan kegiatan ini dimulai dari tahap persiapan. Pada tahap ini yang harus dilakukan adalah mempelajari referensi yang berkaitan dengan media 
http:/jurnalstkippersada.acid/jumal/index:php/JPMR pembelajaran berbasis e-learning (edublog) dan mengumpulkan atau merangkum materi yang akan disampaikan. Pada tahap ini, media power point juga akan dibuat untuk disampaikan kepada guru.

Tahap kedua adalah implementasi. Pada tahap ini ada dua sesi, yaitu pengantar dan aplikasi. Guru diberikan bentuk media pembelajaran berdasarkan elearning (edublog). Dalam sesi ini mereka juga memberikan penjelasan tentang aplikasi mereka. Kemudian, sesi berikutnya adalah sesi untuk menerapkan media pembelajaran berbasis e-learning.

Pada tahap penerapan media pembelajaran ini berdasarkan pada e-learning (edublog), guru diberi kesempatan dan fleksibilitas untuk mencoba dan menerapkan media tersebut. Kemudian dalam penerapannya didampingi oleh peneliti.

\section{HASIL DAN PEMBAHASAN}

Kegiatan pertama yang dilakukan adalah sosialisasi kegiatan. Dalam sesi ini, maksud dan tujuan dari kegiatan dan implementasi teknis disampaikan. Selain itu, guru diberi kesempatan untuk menggambarkan masalah dalam kesulitan penggunaan media pembelajaran. Hal berikutnya adalah penyampaian materi berdasarkan analisis kebutuhan guru, yaitu tentang media pembelajaran online berbasis media sosial (edublog). Kemudian guru mencoba media ditemani oleh pembicara. Mereka kemudian berlatih sesuai dengan materi yang disediakan dan mencoba menerapkannya segera setelah sesi pengiriman materi.

Dalam sesi praktik, para guru menanyakan banyak hal tentang media dan berusaha keras untuk menerapkannya. Salah satu guru berasumsi bahwa ini adalah pertama kalinya baginya dalam menggunakan media elektronik (edublog), dalam proses pembelajaran mengajar sehari-hari, ia biasanya menggunakan media konvensional.

Para guru merasa senang menggunakan media ini karena sangat menarik dengan menggunakan suara, gambar dan alat diskusi. Namun, mereka tidak percaya bahwa media ini akan berhasil ketika diterapkan di ruang kelas. Mereka merasa bahwa sebagian besar siswa tidak antusias (bermotivasi tinggi) dalam belajar.

\section{KESIMPULAN}

Dalam hal pengabdian masyarakat, dalam hal ini targetnya adalah guru di Madrasah Aliyah Annamirah dengan fokus pada media pembelajaran. Hasil yang 


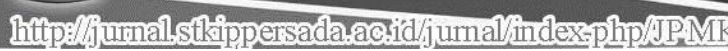

diperoleh adalah guru dapat menggunakan media pembelajaran berbasis e-learning (edublog) dalam proses belajar mengajar nanti. Ini adalah sesuatu yang baru bagi guru dalam menggunakan media online. Hasil yang diperoleh untuk peneliti adalah bahwa media ini sangat membantu bagi guru dalam kaitannya dengan menggunakan media berbasis online sehingga siswa merasa senang dan senang dalam proses pembelajaran dan tidak membosankan.

\section{References}

Arikunto, Suharsimi. 2003. Prosedur Penelitian Suatu Praktek. Bina. Aksara:

Jakarta.

Azibila, Muhammad. Problematika yang di hadapi Guru Bahasa Indonesia, Artikel.Diaksestanggal Februari 2016.

Darmawan, Deni. PendidikanTeknologiInformasid anKomunikasi, RemajaRosdakarya, 2013.

Ibrahim. 2000. Pembelajaran Kooperatif. University Press: Surabaya.

Masnur Muslich. 2009. KTSP Pembelajaran Berbasis Kompetensi dan Kontestual. Bumi Aksara, Jakarta.
Trianto. E-ISSN 25ㅁ-5800

(2007). Model-model

Pembelajaran Inovatif Berorientasi Konstruktivis. Jakarta: Prestasi Pustaka.

Rusman. 2012. Model-Model Pembelajaran Mengembangkan Profesionalisme

Guru. Rajawali Press: Jakarta. 